\title{
Monitoring of the Eyjafjallajökull volcanic aerosol plume over the Iberian Peninsula by means of four EARLINET lidar stations
}

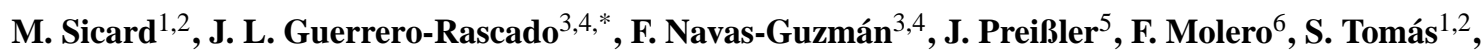 \\ J. A. Bravo-Aranda ${ }^{3,4}$, A. Comerón ${ }^{1}$, F. Rocadenbosch ${ }^{1,2}$, F. Wagner ${ }^{5}$, M. Pujadas ${ }^{6}$, and L. Alados-Arboledas ${ }^{3,4}$ \\ ${ }^{1}$ Dept. of Signal Theory and Communications, Remote Sensing Lab., Universitat Politècnica de Catalunya, Barcelona, Spain \\ ${ }^{2}$ Institut d'Estudis Espacials de Catalunya - Aeronautics and Space Research Center (IEEC-CRAE), Universitat Politècnica \\ de Catalunya, Barcelona, Spain \\ ${ }^{3}$ Andalusian Centre for Environmental Research, Junta de Andalucía, University of Granada, Granada, Spain \\ ${ }^{4}$ Applied Physics Department, University of Granada, Granada, Spain \\ ${ }^{5}$ Centro de Geofísica de Évora, Évora, Portugal \\ ${ }^{6}$ Centro de Investigaciones Energéticas Medioambientales y Tecnológicas, Madrid, Spain \\ *now at: Centro de Geofísica de Évora, Évora, Portugal
}

Correspondence to: M. Sicard (msicard@tsc.upc.edu)

Received: 19 October 2011 - Published in Atmos. Chem. Phys. Discuss.: 3 November 2011

Revised: 17 February 2012 - Accepted: 6 March 2012 - Published: 30 March 2012

\begin{abstract}
Lidar and sun-photometer measurements were performed intensively over the Iberian Peninsula (IP) during the eruption of the Eyjafjallajökull volcano (Iceland) in April-May 2010. The volcanic plume reached all the IP stations for the first time on 5 May 2010. A thorough study of the event was conducted for the period 5-8 May. Firstly, the spatial and temporal evolution of the plume was described by means of lidar and sun-photometer measurements supported with backtrajectories. The volcanic aerosol layers observed over the IP were rather thin $(<1000 \mathrm{~m})$ with a top height up to $11-12 \mathrm{~km}$. However, in some cases at the beginning of the period the thickness of those layers reached several kilometers in Évora and Madrid. The optical thicknesses associated to those layers were rather low (between 0.013 and 0.020 in average over the whole period), with peak values near 0.10 detected on 7 May. Secondly, the volcanic aerosols were characterized in terms of extinction and backscatter coefficients, lidar ratios, Ångström exponents and linear particle depolarization ratio. Lidar ratios at different sites varied between 30 and $50 \mathrm{sr}$ without a marked spectral dependency. Similar extinction-related Ångström exponents varying between 0.6 and 0.8 were observed at different sites. The temporal evolution of the backscatter-related Ångström exponents points out a possible decrease of the volcanic particle size as the plume moved from west to east. Particle depolarization ratios on the order of $0.06-0.08$ confirmed the coexis-
\end{abstract}

tence of both ash and non-ash particles. Additionally, profiles of mass concentration were obtained with a method using the opposite depolarizing effects of ash particles (strongly depolarizing), non-ash particles (very weakly depolarizing), and sun-photometer observations. In Granada the ash mass concentration was found to be approximately 1.5 times higher than that of non-ash particles, and probably did not exceed the value of $200 \mathrm{\mu gm}^{-3}$ during the whole event.

\section{Introduction}

The eruption of the Eyjafjallajökull volcano, an ice-covered stratovolcano with a summit elevation of $1666 \mathrm{~m}$ a.s.l. situated in southern Iceland, started on 14 April 2010 and stopped on 21 May 2010. This eruption threw volcanic aerosols with variable intensity several kilometers up into the atmosphere (Langmann et al., 2011) which were transported mostly towards Europe and led to air travel disruption in northern and central Europe from 15 April onwards and in southeastern Europe in May 2010. Many major northern and central European countries closed their airspace completely during several days. Several thousands of flights, which affected several millions of passengers, were canceled. From a climate point of view, since no significant amount of ash and sulphur dioxide was injected into the stratosphere, their

Published by Copernicus Publications on behalf of the European Geosciences Union. 
residence time in the atmosphere was rather small compared to other recent eruptions (Parker et al., 1996). Thus the impact of the Eyjafjallajökull eruption on the Earth's radiative budget and climate is very unlikely.

The lidar technique is one of the most relevant remote sensing tools with which to study atmospheric aerosols. In the past, volcanic aerosols have been observed by lidars a long time after they have been ejected in the stratosphere (Langford et al., 1995; Borrmann et al., 1995; Wandinger et al., 1995; Di Girolamo et al., 1996) and less frequently in the troposphere (Pappalardo et al., 2004; Villani et al., 2006; Wang et al., 2008). The Eyjafjallajökull volcanic plume was followed in near-real time by many scientists from different fields of atmospheric sciences all over the world but especially in Europe since the very first day of the eruption. While many results obtained in northern and central Europe have already been published (Ansmann et al., 2010, 2011; Flentje et al., 2010; Wiegner et al., 2011;, only very few results about the situation in southern Europe can be found in peer-reviewed literature (Papayannis et al., 2011; Mona et al., 2011; Toledano et al., 2011).

Most of the 27 lidar stations that formed EARLINET (European Aerosol Research Lidar Network) at the time of the study started monitoring the Eyjafjallajökull event on 15 April (Pappalardo et al., 2010). Four of those stations are situated in the Iberian Peninsula (IP) and are members of SPALINET (Spanish and Portuguese Aerosol Lidar Network) (Sicard et al., 2009). While the plume travelled sometimes less than two days before it was observed at north and central European stations at altitudes not higher than $10 \mathrm{~km}$, it took at least three to five days to reach the IP where it was detected at altitudes as high as 11-12 km (Pappalardo et al., 2012). The volcanic aerosol layers that reached the IP were very faint compared to those observed in northern and central Europe. For those reasons it is assumed that the volcanic plumes observed over the IP have different properties in terms of composition and particle size compared to those observed over northern and central Europe. The peculiar situation of the IP with respect to the transport pattern of the volcanic plumes makes lidar measurements over the IP suitable to evaluate dispersion model boundary conditions. In a preliminary study, Molero et al. (2010) made a simple comparison between model predictions such as EURAD (EURopean Air Pollution Dispersion, http://www.eurad.unikoeln.de/index_e.html) and FLEXPART (http://transport. nilu.no/flexpart) and vertical profiles obtained by four lidar systems over the IP. More extended analysis were made over the IP (Toledano et al., 2011) and over the Atlantic Ocean and northern and central Europe (Stohl et al., 2011).

Until 5 May only sporadic, isolated volcanic plumes were observed over the IP, especially on 19 and 20 April. On 4 May, a change in the synoptic situation caused the strongest intrusion of volcanic aerosols over the IP from the Atlantic Ocean eastward. This paper focuses on the monitoring of the volcanic plume over the IP observed by four lidar sta- tions during the period 5-8 May 2010. We only concentrate on lofted volcanic aerosol plumes, i.e. not coupled to the planetary boundary layer (PBL), because in situ measurements in the PBL are not available at all sites to differentiate volcanic aerosols from local aerosols and to study the mixing processes occurring in the PBL. In this paper, we refer to volcanic aerosols and not only volcanic ash. Volcanic aerosols are a mixture of ash particles (volcanic glass, minerals and lithic fragments), volcanic gases such as sulphur dioxide $\left(\mathrm{SO}_{2}\right)$, carbon dioxide $\left(\mathrm{CO}_{2}\right)$ and hydrogen $\left(\mathrm{H}_{2}\right)$, and droplets of water vapor $\left(\mathrm{H}_{2} \mathrm{O}\right)$, hydrochloric acid $(\mathrm{HCl})$ and hydrofluoric acid (HF) among others (http:// volcanoes.usgs.gov/hazards/gas/s02aerosols.php). Ash particles fall out quite rapidly due to their large mass so that over the IP, far away from the source, their contribution may be significantly reduced. On the contrary, the residence time of sulfate aerosols is in general longer for they can reside in the atmosphere for several weeks or months.

This paper is organized as follows: Sect. 2 briefly presents the instrumentation; in Sect. 3 the spatial and temporal evolution of the volcanic plume over the IP is described; and in Sect. 4 the vertical characterization of the volcanic aerosols is presented in terms of their optical properties and an estimate of their mass concentration is shown. Conclusions are made in Sect. 5.

\section{Instruments}

\subsection{Lidars}

The four lidar systems involved in this study all belong to EARLINET and SPALINET. A short description of them can be found in Sicard et al. (2009, 2011a). The principal characteristics of those systems are presented in Table 1. The institutions involved are:

- Centro de Geofísica de Évora, Évora (Portugal, $38.57^{\circ} \mathrm{N}, 7.91^{\circ} \mathrm{W}, 293 \mathrm{~m}$ a.s.l.);

- Centro de Investigaciones Energéticas Medioambientales y Tecnológicas, Madrid (Spain, $40.46^{\circ} \mathrm{N}, 3.72^{\circ} \mathrm{W}$, 665 m a.s.l.);

- Universidad de Granada, Granada (Spain, $37.16^{\circ} \mathrm{N}$, $3.58^{\circ} \mathrm{W}, 680 \mathrm{~m}$ a.s.l.);

- Universidad Politécnica de Cataluña, Barcelona (Spain, $41.39^{\circ} \mathrm{N}, 2.11^{\circ} \mathrm{E}, 115 \mathrm{~m}$ a.s.1.).

All four systems participated in an intercomparison campaign in Madrid from 18 October to 5 November 2010 in the framework of the EARLINET quality assurance program and were satisfactorily compared to the reference system of Potenza, Italy (for more details see Freudenthaler et al., 2011). Coordinated measurements started on 15 April 2010 and intensified on 5 May as the intrusion strengthened. 
Table 1. Some characteristics of the lidar systems involved in the study.

\begin{tabular}{lrrrr}
\hline $\begin{array}{l}\text { Station } \\
\text { Country }\end{array}$ & $\begin{array}{r}\text { Évora } \\
\text { Portugal }\end{array}$ & $\begin{array}{r}\text { Madrid } \\
\text { Spain }\end{array}$ & $\begin{array}{r}\text { Granada } \\
\text { Spain }\end{array}$ & $\begin{array}{r}\text { Barcelona } \\
\text { Spain }\end{array}$ \\
\hline $\begin{array}{l}\text { Elastic } \\
\text { wavelengths } \\
(\mathrm{nm})\end{array}$ & $1064,532,355$ & 532 & $1064,532,355$ & 532,355 \\
\hline $\begin{array}{l}\text { Raman } \\
\text { wavelengths } \\
\text { (nm) }\end{array}$ & 607,387 & 607 & $607,387,408$ & - \\
\hline $\begin{array}{l}\text { Depolarization } \\
\text { Raw resolution } \\
\text { (m) }\end{array}$ & no. & no. & at 532 nm & no. \\
\hline $\begin{array}{l}\text { Full overlap } \\
\text { height (m) }\end{array}$ & 30 & 3.75 & 7.5 & 7.5 \\
\hline $\begin{array}{l}\text { Maximum } \\
\text { range (km) }\end{array}$ & 500 & 400 & 300 & 400 \\
\hline
\end{tabular}

All measurements were inverted using the two-component elastic lidar inversion algorithm (Fernald, 1984; Sasano and Nakane, 1984; Klett, 1985) and a constant lidar ratio of $50 \mathrm{sr}$. All nighttime measurements were also inverted using the Raman lidar inversion algorithm (Ansmann et al., 1990, 1992).

\subsection{Sun-photometers}

Some columnar aerosol properties of interest were measured by CIMEL sun-sky photometers in Évora, Granada, and Barcelona. For Madrid, the sun-photometer in Cáceres (located approximately $250 \mathrm{~km}$ southwest of Madrid) was used. Escudero et al. (2006) showed that for long-range transport events, namely Saharan dust, PM10 concentrations from several Iberian Peninsula EMEP stations correlated reasonably well. For this reason, the Cáceres aerosol optical thickness is assumed to be a good indicator of longrange transport aerosols in the same way as PM10 concentrations. All sun-photometers are part of the Aerosol Robotic Network (AERONET, http://aeronet.gsfc.nasa.gov/) (Holben et al., 1998) and despite the small quantities of volcanic aerosols that reached the IP, the capability of AERONET sun-photometer data to detect them has been extensively demonstrated by Toledano et al. (2011). The highest AERONET level available was used: Level 1.5 (cloud screened data) at Évora and Level 2.0 (quality assured data) at Madrid, Granada and Barcelona. The instrument provides information about, among other properties, the aerosol optical thickness (AOT) at 340, 380, 440, 500, 675, 870, and $1020 \mathrm{~nm}$ in Évora, Madrid, and Granada, and at 440, 675, 870 and $1020 \mathrm{~nm}$ in Barcelona, as well as the single scattering albedo and the Ångström exponent between pairs of wavelengths. In this paper we used the Ångström exponent provided for the pair $(440,675 \mathrm{~nm})$ at all sites. A common product of AERONET is the fine and coarse mode AOT at $500 \mathrm{~nm}$ (O'Neill et al., 2003). Inversion products such as the volume size distribution are also provided.

\section{Evolution of the Eyjafjallajökull volcanic aerosol plume over the IP: 5-8 May 2010}

\subsection{Synoptic situation}

A complex system developed during the period 5-8 May 2010. Figure 1 shows the synoptic situation over western Europe in terms of sea level pressure for every day of the period 4-9 May at 12:00 UTC. The start of the period is characterized by a deep anticyclone located south of Iceland and west of Ireland, while a low pressure system affected southern France. On 5 and 6 May a front formed in the Atlantic west of the IP's coasts as a new low pressure system appeared at the 40W longitude. During 6-8 May this new low pressure system swept over the Atlantic Ocean eastwards towards the IP leading to pronounced easterly winds starting on 8 May. From 9 May on, this low pressure gradient settled over the north of the IP producing several days of unstable conditions with broken clouds and low intensity rains. Backtrajectories have been calculated with the HYSPLIT (Hybrid Single Particle Lagrangian Integrated Trajectory Model) (Draxler and Rolph, 2003; Rolph, 2003) model provided by NOAA-ARL (National Oceanic and Atmospheric Administration - Air Resources Laboratory) to check the air-masses origin. Figure 2 shows 120-h backtrajectories arriving at the four stations at 6 altitude levels between 500 and $5500 \mathrm{~m}$ with a resolution of $1000 \mathrm{~m}$ for each day. The time of arrival was fixed at 12:00 UTC as an example. In practice the backtrajectories 

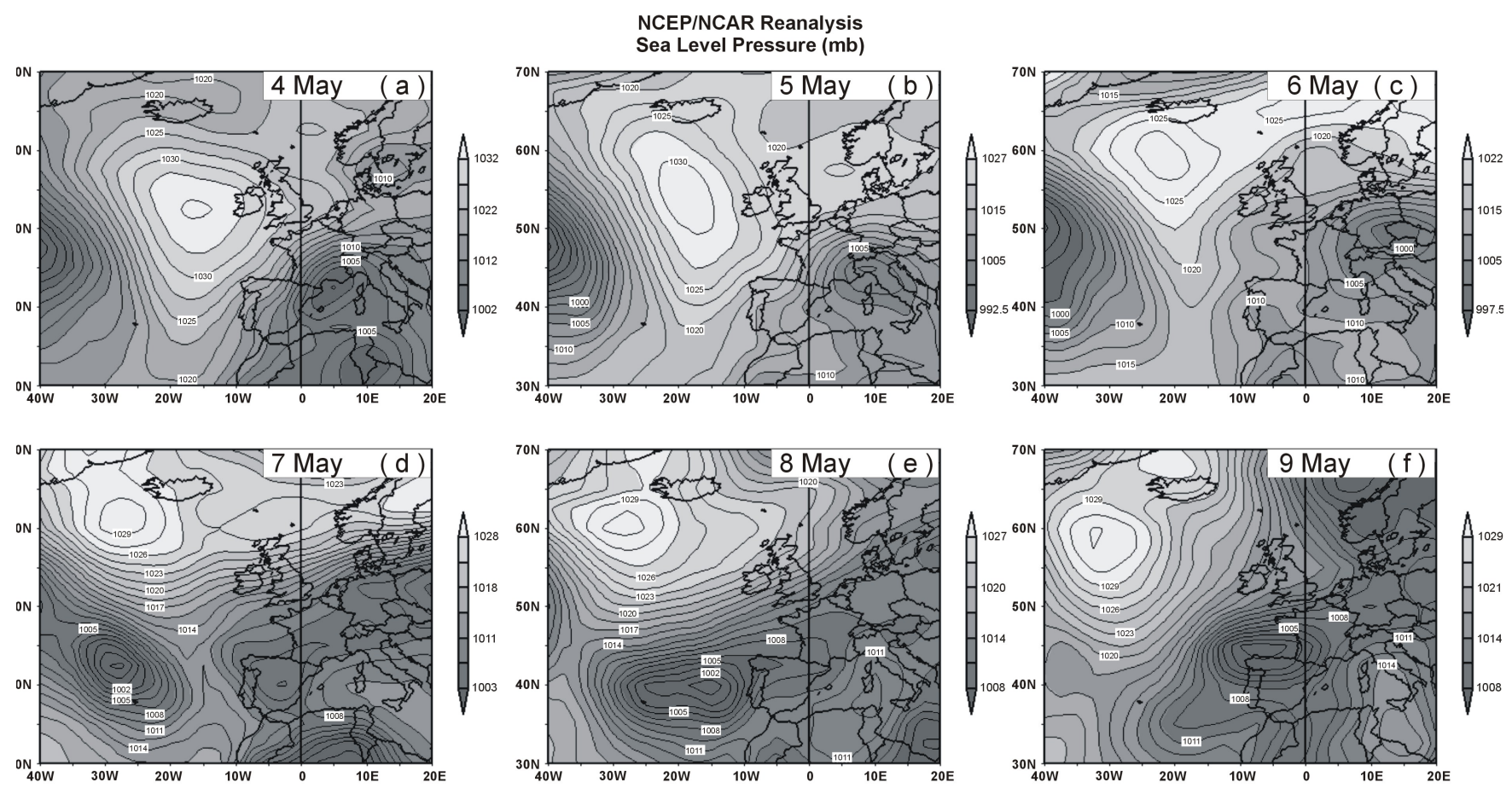

Fig. 1. Synoptic situation at 12:00 UTC on (a) 4, (b) 5, (c) 6, (d) 7, (e) 8 and (f) 9 May 2010. Dark and light and colors represent low and high pressures, respectively.

were checked case by case at each station. The length of the trajectories corresponds to 5 days. In Évora and Madrid, a transport over Iceland was visible every day at two or more altitude levels. In Évora the backtrajectories were similar on 5 and 6 May: all altitude levels show a transport over Iceland 3 to 4 days prior to the plume arrival. On 7 May the same pattern persisted except for the 500-m altitude level. On 8 May only the 500- and 1500-m altitude levels showed transport over Iceland approximately 5 days prior to the plume arrival. In Madrid on 5 May, only air masses at altitude levels above $3500 \mathrm{~m}$ travelled over Iceland 2 to 3 days prior to arrival. On 6 and 7 May the situation was similar to that of Évora. On 8 May only the altitude levels below $2500 \mathrm{~m}$ showed transport over Iceland approximately 4 days prior to arrival. The situation in Granada and Barcelona was slightly different. On 5 May mesoscale transports dominate. On 6 May the air masses at altitude levels below $3500 \mathrm{~m}$ were all transported over Iceland 5 days (at 500 and $1500 \mathrm{~m}$ ) and 3-4 days (at 2500 and $3500 \mathrm{~m}$ ) prior to arrival. On 7 May, all trajectories traveled over Iceland 3 days (Granada) and 4-5 days (Barcelona) prior to arrival. On 8 May, only the altitude levels below $2500 \mathrm{~m}$ showed clearly a transport over Iceland with travelling times of 4 to 5 days.

In summary, according to the synoptic situation and the backtrajectory analysis, the volcanic aerosol plume entered the IP from west-northwest at all altitude levels and with relatively short transport times from Iceland between 2 and 4 days. Along the intrusion, the plume transported from Ice- land reached the IP at lower altitudes and longer transport times. In the southern and eastern IP the plume appeared on 6 May at lower altitudes.

\subsection{Spatial and temporal evolution of the volcanic aerosol plume over the IP}

The spatial and temporal evolution of the volcanic aerosol (VA) plume over the IP is analyzed through the time series of vertical profiles of range-square corrected lidar signals (RSCS).

Figure 3 shows the RSCS time series of the four Iberian stations over the whole period. All the measurements performed by the four stations including cloudy and clear scenes have been plotted for completeness. The height, if not otherwise stated, is reported above sea level (a.s.l.). Below the lidar time series, the sun-photometer total, coarse and fine mode AOT at $500 \mathrm{~nm}$, as well as the Ångström exponent calculated between the wavelengths of 440 and $675 \mathrm{~nm}$ are reported for each station. Figure 4 shows the AOT of the lofted layers of VA, hereinafter called $\mathrm{AOT}_{\mathrm{VA}}$, at $532 \mathrm{~nm}$ measured by the lidar stations as a function of height and time with a time resolution of $1 \mathrm{~h}$. In this section, $\mathrm{AOT}_{\mathrm{VA}}$ was calculated by the integration of the backscatter profiles inverted with the two-component elastic lidar inversion algorithm multiplied by a constant lidar ratio of $50 \mathrm{sr}$. This value is a good approximation in view of the lidar ratios found in Ansmann et al. (2010) and the results presented in Sect. 4 of 

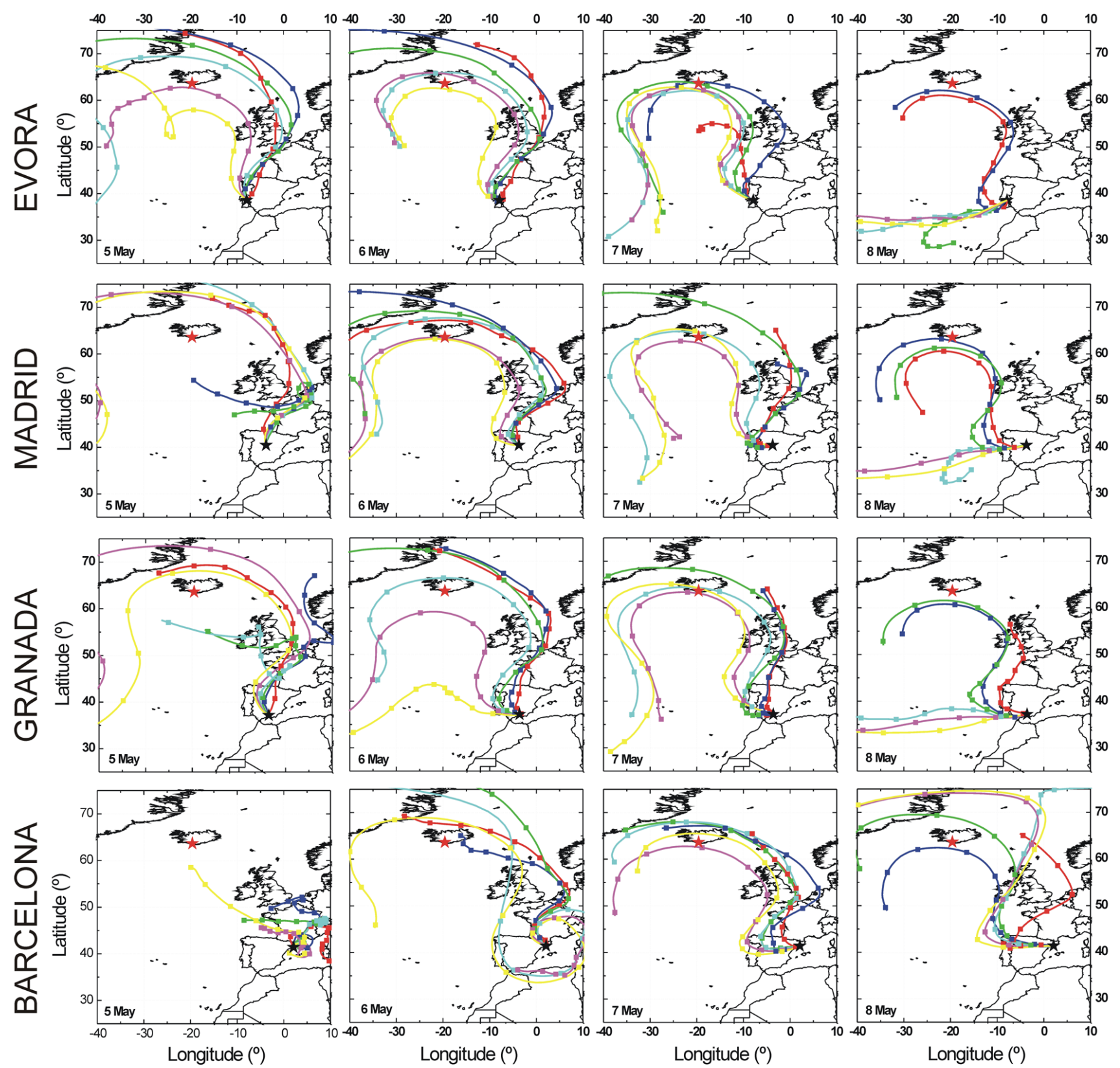

Fig. 2. 120-h (5 days) backtrajectories arriving in Évora, Madrid, Granada and Barcelona at 12:00 UTC on 5, 6, 7 and 8 May 2010 at 500 (red), 1500 (blue), 2500 (green), 3500 (cyan), 4500 (purple) and $5500 \mathrm{~m}$ (yellow) above ground level. The red star indicates the location of the Eyjafjallajökull volcano.

this paper. The layers below $2 \mathrm{~km}$ that might have been coupled to the PBL have been discarded in order to minimize the influence of local aerosols in the analysis. The measurements with clouds or optically extremely thin VA layers (leading to large errorbars in the retrieval of the optical coefficients) have been discarded in Fig. 4. The thickness of lofted VA layers is hereinafter called $\Delta h_{\mathrm{VA}}$. Table 2 gives the daily mean of the $\mathrm{AOT}_{\mathrm{VA}}, \overline{\mathrm{AOT}_{\mathrm{VA}}}$, and of the layer thickness, $\overline{\Delta h_{\mathrm{VA}}}$, of the lofted VA layers. The minimum and maximum values of $\mathrm{AOT}_{\mathrm{VA}}$ and $\Delta h_{\mathrm{VA}}$ are also reported in Table 2 to show their large variability.

The uncertainty of $\mathrm{AOT}_{\mathrm{VA}}$ can be calculated as the sum of the systematic error and the statistical error. Both terms are given in Eqs. (A2) and (A4) of Appendix A. The systematic error has been calculated using the relative errors of the backscatter coefficient given in Sicard et al. (2009) while 


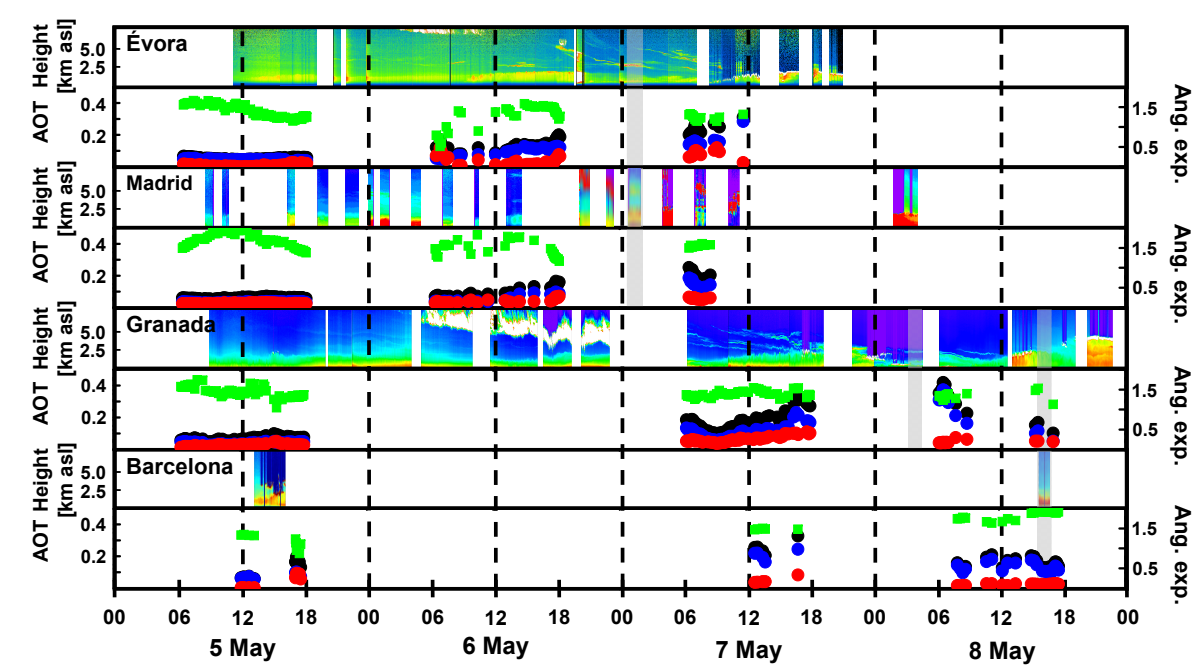

Fig. 3. Evolution of the lidar range-square corrected signal from 5 to 8 May, 2010, at Évora, Madrid, Granada and Barcelona. Below the lidar signal time series the sun-photometer total (black circles), coarse mode (red circles) and fine mode (blue circles) AOT at $500 \mathrm{~nm}$ are reported. The Ångström exponent is reported as green squares (right axis). The vertical gray bars indicate the time periods discussed in Sect. 4.

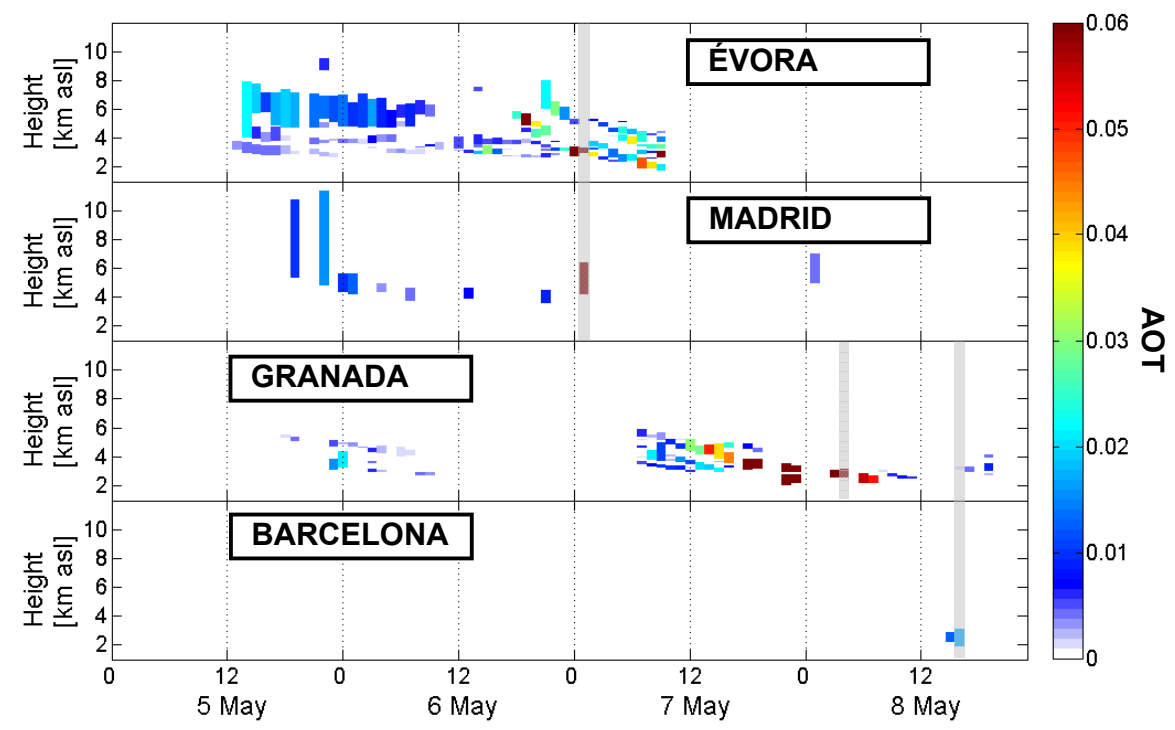

Fig. 4. AOT of lofted VA layers at $532 \mathrm{~nm}$ versus height from 5 to 8 May 2010. The vertical gray bars indicate the time periods discussed in Sect. 4.

the statistical error has been calculated directly with the statistical error of the backscatter coefficient provided for each inversion (EARLINET products such as the backscatter coefficient are provided with their statistical error). For all three wavelengths of 355,532 , and $1064 \mathrm{~nm}$, the uncertainty of $\mathrm{AOT}_{\mathrm{VA}}$ is $15-20 \%$ for $\mathrm{AOT}_{\mathrm{VA}} \geq 0.01$ (the systematic errors dominate) and $20-30 \%$ for $0.01>\mathrm{AOT}_{\mathrm{VA}} \geq 0.002$ (both errors are similar). Taking into account the low values of $\mathrm{AOT}_{\mathrm{VA}}$ found, those uncertainties are acceptable.

On 5 May the first VA plume was detected in Évora just before noon, in Madrid around 16:00 UTC and in Granada around 17:00 UTC. The Barcelona station was covered with clouds part of the afternoon. Clearly marked VA layers were observed above the PBL and below 5-6 km (Fig. 3). However, over the 3 stations the rest of the troposphere was not aerosol-free (Fig. 4), indicating a strong vertical dispersion of the plume. No vertical motion is noticeable until around midnight when the plume shows a downward motion in Granada. The sun-photometer AOT did not present any significant increase which also indicates optically thin 
Table 2. Mean optical (at $532 \mathrm{~nm}$ ) and spatial thickness of the lofted VA layers at the 4 stations from 5 to 8 May 2010 . The minimum and maximum values (min, max) of $\mathrm{AOT}_{\mathrm{VA}}$ and $\Delta h_{\mathrm{VA}}$ are also reported.

\begin{tabular}{|c|c|c|c|c|c|c|}
\hline Station & & 5 May & 6 May & 7 May & 8 May & 5-8 May \\
\hline Évora & $\begin{array}{l}\overline{\mathrm{AOT}_{\mathrm{VA}}} \\
(\min , \max ) \\
\overline{\Delta h_{\mathrm{VA}}(\mathrm{m})} \\
(\min , \max )\end{array}$ & $\begin{array}{l}0.008 \\
(<0.002,0.022) \\
1104 \\
(179,3885)\end{array}$ & $\begin{array}{l}0.009 \\
(<0.002,0.065) \\
543 \\
(60,2332)\end{array}$ & $\begin{array}{l}0.025 \\
(0.002,0.107) \\
360 \\
(89,777)\end{array}$ & $\begin{array}{l}- \\
-\end{array}$ & $\begin{array}{l}0.013 \\
(<0.002,0.107) \\
614 \\
(60,3885)\end{array}$ \\
\hline Madrid & $\begin{array}{l}\overline{\mathrm{AOT}_{\mathrm{VA}}} \\
(\min , \max ) \\
\overline{\Delta h_{\mathrm{VA}}(\mathrm{m})} \\
(\min , \max )\end{array}$ & $\begin{array}{l}0.034 \\
(<0.002,0.016) \\
4240 \\
(750,6600)\end{array}$ & $\begin{array}{l}0.008 \\
(0.004,0.130) \\
1000 \\
(600,1500)\end{array}$ & $\begin{array}{l}0.070 \\
(0.070,0.070) \\
2250 \\
(2250,2250)\end{array}$ & $\begin{array}{l}0.004 \\
(0.004,0.004) \\
2105 \\
(2105,2105)\end{array}$ & $\begin{array}{l}0.020 \\
(<0.002,0.130) \\
2098 \\
(600,6600)\end{array}$ \\
\hline Granada & $\begin{array}{l}\overline{\mathrm{AOT}_{\mathrm{VA}}} \\
(\min , \max ) \\
\overline{\Delta h_{\mathrm{VA}}(\mathrm{m})} \\
(\min , \max )\end{array}$ & $\begin{array}{l}0.007 \\
(<0.002,0.016) \\
422 \\
(262,705)\end{array}$ & $\begin{array}{l}0.004 \\
(<0.002,0.021) \\
325 \\
(82,1147)\end{array}$ & $\begin{array}{l}0.026 \\
(<0.002,0.137) \\
412 \\
(82,1230)\end{array}$ & $\begin{array}{l}0.027 \\
(<0.002,0.106) \\
343 \\
(113,667)\end{array}$ & $\begin{array}{l}0.020 \\
(<0.002,0.137) \\
382 \\
(82,1230)\end{array}$ \\
\hline Barcelona & $\begin{array}{l}\overline{\mathrm{AOT}_{\mathrm{VA}}} \\
(\min , \max ) \\
\overline{\Delta h_{\mathrm{VA}}(\mathrm{m})} \\
(\min , \max )\end{array}$ & $\begin{array}{l}- \\
-\end{array}$ & - & $\begin{array}{l}- \\
-\end{array}$ & $\begin{array}{l}0.015 \\
(0.013,0.017) \\
950 \\
(700,1200)\end{array}$ & $\begin{array}{l}0.015 \\
(0.013,0.017) \\
950 \\
(700,1200)\end{array}$ \\
\hline
\end{tabular}

VA layers. Figure 4 shows clearly the large vertical dispersion in Évora with discontinued layers between 2.3 and $9.3 \mathrm{~km}$. In Madrid the first lofted layers of VA detected above the PBL are very broad (5400 and $6600 \mathrm{~m}$ thick). They were detected between 4.0 and $11.4 \mathrm{~km}$ - which according to the Madrid radiosounding launched on 6 May at 00:00 UTC, which detected the tropopause around $10.6 \mathrm{~km}$, was inside the stratosphere - without clear discontinuity while in Granada much thinner VA layers $\left(\overline{\Delta h_{\mathrm{VA}}}=422 \mathrm{~m}\right)$ are detected. Both in Granada and in Évora the mean optical thickness of the VA layers was very low around 0.0070.008 which represents less than $10 \%$ of the columnar AOT. In Madrid the first VA layers detected had an $\mathrm{AOT}_{\mathrm{VA}}$ lower than 0.016 which indicates extremely optically thin layers given their large vertical extension. It is worth noting that the CALIOP (Cloud-Aerosol Lidar with Orthogonal Polarization) lidar flying on board CALIPSO (Cloud-Aerosol Lidar and Infrared Pathfinder Satellite Observations) (Winker et al., 2009) made an overpass over the eastern IP on 6 May around 02:40 UTC and also detected very thin aerosol plumes identified as dust and polluted dust - in which categories volcanic aerosols do fit - up to $10 \mathrm{~km}$.

At the beginning of 6 May, the same situation persisted in Évora and Madrid whereas Granada was covered by midand high-altitude clouds. VA layers were clearly visible above $2.5 \mathrm{~km}$ in Évora and between 2.5 and $7.0 \mathrm{~km}$ in Madrid throughout the day. The sun-photometer AOT increased substantially during the day: it passed from 0.09 at noon in both stations to 0.20 at 18:15 UTC in Évora and to 0.16 at 18:00 UTC in Madrid. In both stations the Ångström exponent slightly decreased compared to the previous day. The coarse mode AOT was constant in both stations which indicates that the total AOT increase was due to fine particles only. Slightly after 17:30 UTC, a sudden increase of the AOT was visible in both stations. It is associated to an increase of the coarse mode AOT and a decrease of the Ångström exponent which indicated the intrusion of a new layer formed by coarse particles. The Évora RSCS time series indicated the intrusion of a well defined VA layer above $5 \mathrm{~km}$ with a clear downward motion. The same intrusion was observed in Madrid after 21:00 UTC but there a cirrus cloud was embedded in the descending VA layer between 5 and $8 \mathrm{~km}$. In terms of $\mathrm{AOT}_{\mathrm{VA}}$, the main layer observed in Évora on 5 May remained during the first half of 6 May as very thin layers appear below. The new layers which appeared above $5 \mathrm{~km}$ after 18:00 UTC had higher optical thicknesses. In Madrid the VA layers were more stable than on the previous day: AOT $_{\mathrm{VA}}$ oscillated around 0.008 and $\Delta h_{\mathrm{VA}}$ between 600 and $1500 \mathrm{~m}$. Both in Évora and in Madrid the mean optical thickness of the VA layers was around $0.008-0.009$, i.e. similar to the values on the previous day. One can easily deduce that the columnar AOT increase was due to aerosols trapped in the layers below $2 \mathrm{~km}$ which according to the backtrajectory analysis had been transported over Iceland. Once again, the mean vertical dispersion of the VA layers was stronger in Madrid $\left(\overline{\Delta h_{\mathrm{VA}}}=1000 \mathrm{~m}\right)$ than in Évora $\left(\overline{\Delta h_{\mathrm{VA}}}=543 \mathrm{~m}\right)$. In Granada very thin layers $\left(\overline{\mathrm{AOT}_{\mathrm{VA}}} \approx 0.004, \overline{\Delta h_{\mathrm{VA}}}=325 \mathrm{~m}\right)$ with a downward motion were observed between 2 and $5 \mathrm{~km}$ before noon. No sun-photometer data is available.

On 7 May several descending VA layers were detected over Évora between 2 and $6 \mathrm{~km}$, which were optically thicker than those observed on 6 May. Shortly before noon, clouds started developing on top of the PBL preventing a further analysis. In Madrid clouds were present on top of the PBL from 04:00 to 05:00 UTC, VA layers were observed between 07:00 and 08:00 UTC and later clouds were again embedded 
in the VA layers between 2 and $5 \mathrm{~km}$. In Granada, a complex situation similar to that in Évora was observed in the morning. In both Évora and Madrid, the sun-photometer AOT (and essentially the fine mode AOT) had increased compared to the previous day while the Ångström exponent had no marked trend. In Granada two AOT increases associated with a slight increase of the Ångström exponent were observed after 09:30 and 15:30 UTC. In both cases, the Granada RSCS time series indicated the intrusion of new well-defined VA layers. In Évora, while the optical thickness of the VA layers had increased $\left(\overline{\mathrm{AOT}_{\mathrm{VA}}} \approx 0.025\right)$ compared to 6 May, their thickness had decreased $\left(\overline{\Delta h_{\mathrm{VA}}}=360 \mathrm{~m}\right)$. This indicates smaller and optically thicker VA layers. In Granada, the VA layers presented roughly the same characteristics $\left(\overline{\mathrm{AOT}_{\mathrm{VA}}} \approx 0.026, \Delta \overline{h_{\mathrm{VA}}}=412 \mathrm{~m}\right)$. As the day went by, the lowest lofted VA layers got coupled to the PBL both in Évora (in the morning) and Granada (in the afternoon). Those results are supported in the horizontal context by satellite observations such as MODIS (Moderate Resolution Imaging Spectroradiometer) and model simulations such as the Lagrangian particle dispersion model FLEXPART (Toledano et al., 2011) which both showed the arrival of volcanic aerosols in the southwest of the IP.

On 8 May single-layer stratifications predominated: in Madrid a layer was detected between 5.0 and $7.0 \mathrm{~km}$ in the first hours of the day, in Granada between 2.2 and $4.2 \mathrm{~km}$ and in Barcelona between 1.9 and $3.1 \mathrm{~km}$. For information the CALIPSO overpass over the central IP at 13:35 UTC showed aerosol plumes classified as polluted dust up to $6 \mathrm{~km}$. The VA layers were observed at lower altitudes than at the beginning of the period. The total AOT decreased following the variations of the fine mode back to its seasonal mean value (0.10) in Granada (Alados-Arboledas et al., 2003) and oscillated around 0.15 in Barcelona, which also comes to be a seasonal mean value (Sicard et al., 2011b). In Granada, the VA layers had approximately the same $\overline{\mathrm{AOT}_{\mathrm{VA}}}(0.027)$ than on the previous day while their thickness decreased $\left(\overline{\Delta h_{\mathrm{VA}}}=343 \mathrm{~m}\right)$. However, $\mathrm{AOT}_{\mathrm{VA}}$ and $\Delta h_{\mathrm{VA}}$ were not constant throughout the day: the relatively thick layers (spatially and optically, AOT $_{\mathrm{VA}}>0.060$ ) observed at the beginning of the day got thinner as the day went by. In the morning of 8 May, the presence of volcanic aerosols in Barcelona was supported by satellite observations such as MODIS, IASI (Infrared Atmospheric Sounding Interferometer), and SEVIRI (Spin-stabilised Enhanced Visible and Infrared Imager). It is interesting to note that the presence of volcanic aerosols in Granada was supported by FLEXPART column mass simulations for aerosols within the size range 0.75$2.5 \mu \mathrm{m}$ (Toledano et al., 2011) but not for aerosols of all sizes (Stohl et al., 2011).

\section{Characterization of the volcanic aerosols}

The VA characterization has been made through the retrieval of their optical coefficients from nighttime Raman and daytime elastic lidar data, as well as through an estimate of the mass concentration of ash and non-ash particles. The fact that the lofted VA layers of interest in this study were optically very thin (in average $\mathrm{AOT}_{\mathrm{VA}}<0.020$ over all stations and over the whole period) induced lidar signals with very low signal-to-noise ratios which made the inversions, and in particular the nighttime Raman inversions, quite difficult. After a careful review of all the good quality inversions available, three cases have been selected and are presented next (indicated in the time scale of Figs. 3 and 4 by gray bars):

- Raman inversion comparison between Évora and Madrid on 7 May at 01:00 UTC,

- Raman inversion at Granada on 8 May at 04:00 UTC, and

- Elastic inversion comparison between Granada and Barcelona on 8 May at 16:00 UTC.

The optical characterization has been made in terms of aerosol extinction, $\alpha$, and backscatter, $\beta$, coefficients, lidar ratios at $355 \mathrm{~nm}, S_{355}$, and at $532 \mathrm{~nm}, S_{532}$, the $\alpha$-related Ångström exponent at $355 / 532 \mathrm{~nm}\left(\mathrm{AE}_{355-532}^{\alpha}\right)$ and the $\beta$ related Ångström exponents at $355 / 532 \mathrm{~nm}\left(\mathrm{AE}_{355-532}^{\beta}\right)$ and at $532 / 1064 \mathrm{~nm}\left(\mathrm{AE}_{532-1064}^{\beta}\right)$, as well as the linear particle depolarization ratio, $\delta$, when available. In this section $\mathrm{AOT}_{\mathrm{VA}}$ was calculated as the integration of the extinction profiles when Raman measurements were available and otherwise as the integration of the backscatter profiles multiplied by a constant lidar ratio of $50 \mathrm{sr}$ in a first approximation (see Sect. 3.2).

\subsection{Retrieval of the optical coefficients}

\subsubsection{May 2010, 01:00 UTC, Évora-Madrid}

Those two measurements reflect some of the optically thickest layers observed during the period 5-8 May, 2010 (see Fig. 4). The optical characterization is shown in Fig. 5. The VA layer in Évora is about 1-km thick and is located between 2.65 and $3.70 \mathrm{~km}$. AOT $\mathrm{VA}$ is $0.099,0.070$ and 0.050 at 355 , 532 and $1064 \mathrm{~nm}$, respectively. The bottom part of the optical coefficient ( $\alpha$ and $\beta$ ) profiles is shown as reference. In Madrid the VA layer is observed roughly between 4.2 and $6.8 \mathrm{~km}$ and has an $\mathrm{AOT}_{\mathrm{VA}}$ of 0.095 at $532 \mathrm{~nm}$. For the sake of clarity the Évora profiles are not represented above $4.0 \mathrm{~km}$ and those of Madrid below $4.0 \mathrm{~km}$. The numbers in the plots of the lidar ratio and Ångström exponent indicate the mean values plus standard deviation of the profiles in the VA layers. The lidar ratios retrieved in the VA layer in Évora are $39 \pm 10$ and $32 \pm 4 \mathrm{sr}$ at 355 and $532 \mathrm{~nm}$, respectively, Those 


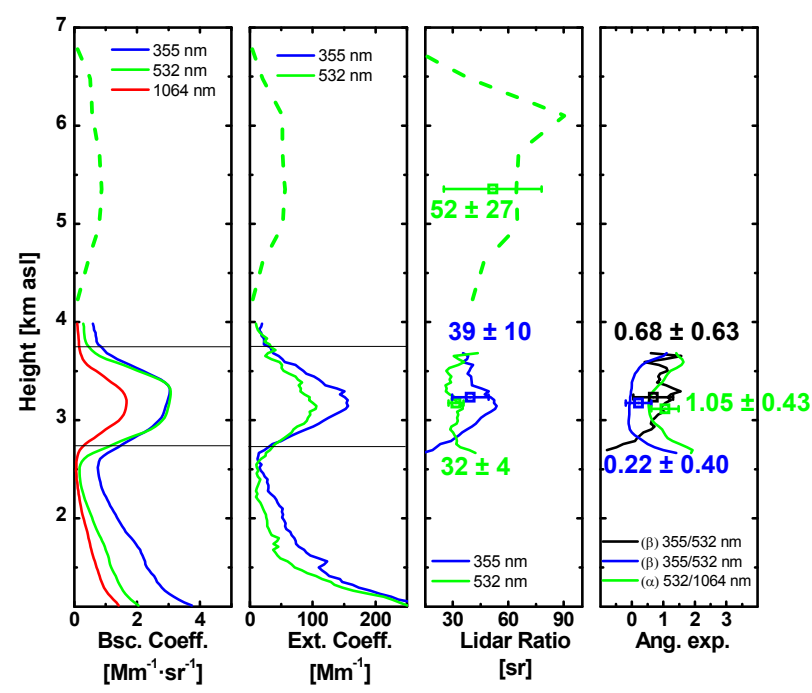

Fig. 5. Volume backscatter and extinction coefficients, lidar ratios, and $\beta$ - (blue and green curves) and $\alpha$-related (black curve) Ångström exponents on 7 May 2010 at 01:00 UTC at Évora (solid lines) and Madrid (dash lines).

values are rather small compared to recent studies (Ansmann et al., 2010; Mona et al., 2011; Wiegner et al., 2011). According to the backtrajectories (Fig. 2), all the air masses arriving over Évora above $2500 \mathrm{~m}$ travelled above the Atlantic Ocean at altitudes well above $3000 \mathrm{~m}$. In absence of anthropogenic emission sources along its way the VA plume probably did not mix with other aerosols during its transport, except maybe with sea salt which are known to have low lidar ratio values. Another possible explanation for the low values of $S_{355}$ and $S_{532}$ is that the air masses dehydrated along their path. This is suggested by Mona et al. (2011) who found that $S_{355}$ decreases when the relative humidity decreases. In Madrid the lidar ratio at $532 \mathrm{~nm}$ was larger: its mean value was $52 \pm 27 \mathrm{sr}$. The backtrajectories arriving over Madrid above $3500 \mathrm{~m}$ were very similar to those arriving over Évora above $2500 \mathrm{~m}$. The most probable hypothesis is that in Madrid, between 4.2 and $6.8 \mathrm{~km}$, proportionally more small particles were present than in Évora between 2.65 and $3.70 \mathrm{~km}$. Therefore small non-ash and small aged ash particles may have dominated, resulting in an increased contribution of non-ash particles which have a larger lidar ratio than ash particles (Ansmann et al., 2011). From Fig. 5, the mean $\mathrm{AE}_{355-532}^{\beta}$ and $\mathrm{AE}_{532-1064}^{\beta}$ in Évora are $0.22 \pm 0.40$ and $1.05 \pm 0.43$, respectively. This indicates that the backscatter coefficient changes more sensitively at longer wavelengths. The mean $\alpha$-related Ångström exponent, $0.68 \pm 0.63$, is relatively low. Such values are representative of rather medium-size particles. They range between very low values of 0.0 to 0.1 observed in Germany (Ansmann et al., 2010) and higher values of 1.0 to 1.4 observed in Italy (Mona et al., 2011).

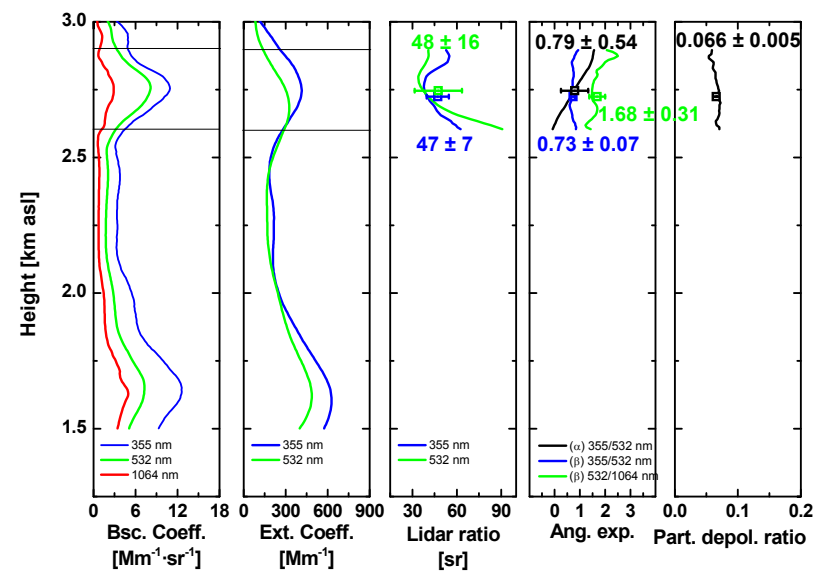

Fig. 6. Volume backscatter and extinction coefficients, lidar ratios, $\beta$ - (blue and green curves) and $\alpha$-related (black curve) Ångström exponents and linear particle depolarization ratio on 8 May 2010 at 04:00 UTC at Granada.

\subsubsection{May 2010, 04:00 UTC, Granada}

This measurement reflects also one of the optically thickest layers observed during the period 5-8 May, 2010. The optical characterization is shown in Fig. 6. The VA layer is located between 2.6 and $2.9 \mathrm{~km}$. The bottom part of the optical coefficient ( $\alpha$ and $\beta$ ) profiles is shown as reference. The extinction and backscatter coefficient profiles reach values in the VA layers on the same order of magnitude than in the layer centered around $1.50-1.75 \mathrm{~km}$ which is supposedly a mixture of local aerosols and VA. AOT VA is $0.106,0.078$ and 0.028 at 355,532 and $1064 \mathrm{~nm}$, respectively, which are quite high values compared to the rest of the period. The lidar ratios retrieved in the VA layer are $47 \pm 7$ and $48 \pm 16 \mathrm{sr}$ at 355 and $532 \mathrm{~nm}$, respectively. Those values are higher than those observed in Évora the day before and are on the same order of magnitude, despite different mixing, of values found in former and ongoing VA studies (Ansmann et al., 2010; Mona et al., 2011; Pappalardo et al., 2012). The mean particle depolarization ratio is 0.06 . This value is much lower than what was observed in plumes consisting mainly of ash in Germany (Ansmann et al., 2010) or of ash and non-ash particles in Italy (Mona et al., 2011) and suggests, if we consider that pure ash and non-ash depolarization ratios are 0.36 and 0.01 , respectively, (Ansmann et al., 2011; see Sect. 4.2), the coexistence of both aerosol types. Below $2.5 \mathrm{~km}$ (not shown) the particle depolarization ratio is around 0.045 , which is a typical value at Granada when only local aerosols are present (J. A. Bravo-Aranda and F. Navas-Guzmán, personal communication, 2011). However, the backtrajectories below $2.5 \mathrm{~km}$ and the synoptic analysis (Sect. 3) indicated that VA are present and mixed with local aerosols in the lowermost layer. The mean value of 0.045 suggests then that the depolarization effect of the VA in the lowermost layer is also on the order 
of 0.045 , which leads to a higher contribution of non-ash particles in the lowermost layer (see Sect. 4.2) than in the 2.6-2.9 km layer. From Fig. 6, the mean $\mathrm{AE}_{355-532}^{\beta}$ and $\mathrm{AE}_{532-1064}^{\beta}$ are $0.73 \pm 0.07$ and $1.68 \pm 0.31$, respectively. This indicates again that the backscatter coefficient changes more sensitively at longer wavelengths. The similar values of $0.73-0.79$ found for the $\alpha$ - and the $\beta$-related Ångström exponents at $355 / 532 \mathrm{~nm}$ clearly reflects the fact that the lidar ratios at both wavelengths are nearly equal. The mean $\alpha$-related Ångström exponent, $0.79 \pm 0.54$, is similar to that in Évora the day before and is also representative of rather medium-size particles.

\subsubsection{May 2010, 16:00 UTC, Granada-Barcelona}

In the afternoon of 8 May, almost all the downward moving VA layers mixed with the upward developing local PBL. Two lofted layers were still visible in Fig. 7: in Granada an extremely thin VA layer was observed between 3.00 and $3.35 \mathrm{~km}$ while in Barcelona a VA layer was visible around $2.2-2.9 \mathrm{~km}$. For the sake of clarity, the Granada profiles are not represented below $3.0 \mathrm{~km}$ and those of Barcelona above $3.0 \mathrm{~km}$. The sun-photometer AOT and the fine mode fraction were respectively around 0.15 and $80 \%$ in Granada and 0.13 and $70 \%$ in Barcelona. In Granada AOT $_{\mathrm{VA}}$ is 0.005 at $355 \mathrm{~nm}$ and 0.002 at $532 \mathrm{~nm}$. At $1064 \mathrm{~nm}$ AOT $_{\mathrm{VA}}$ was less than 0.001. In Barcelona AOT $_{\mathrm{VA}}$ was higher: 0.025 at $355 \mathrm{~nm}$ and 0.010 at $532 \mathrm{~nm}$. In both cases, the AOT of the lofted VA represents a small fraction of the columnar AOT (between 1 and $7 \%$ ). Because those values are extremely low, their interpretation should be done very cautiously. The backscatter coefficients reach very low values which do not exceed $1 \mathrm{Mm}^{-1} \mathrm{sr}^{-1}$. The $\beta$-related Ångström exponents at $355 / 532 \mathrm{~nm}$ oscillate around similar values at both sites $(2.35 \pm 0.20$ and $2.37 \pm 0.27$ in Granada and in Barcelona, respectively). This result indicates that the backscatter coefficient is highly wavelength-dependent at short wavelengths. In Granada the mean $\mathrm{AE}_{532-1064}^{\beta}(1.45 \pm 0.17)$ and the mean particle depolarization ratio $(0.075)$ are similar to their respective values at 04:00 UTC.

\subsection{Estimate of the mass concentration}

Mass concentration is one of the most critical parameters for airspace restrictions related to volcanic aerosol plumes. Shortly after the end of the Eyjafjallajökull eruption, the UK Meteorological Office distinguished between 3 contamination levels: low $\left(<200 \mu \mathrm{gm}^{-3}\right)$, medium (200 to $4000{\mu \mathrm{gm}^{-3}}^{-3}$, and high $\left(>4000 \mu \mathrm{gm}^{-3}\right)$ (Schumann at al., 2011). At present, $2000 \mathrm{\mu gm}^{-3}$ is considered as the maximum tolerable concentration for continuous flight operation.

Mass concentrations have been calculated from backscatter coefficients for ash and non-ash particles. The method used to distinguish between both types of particles is based on the work by Tesche et al. (2009) and refined recently for ash and fine-mode particles by Ansmann et al. (2011). The method uses the opposite depolarizing effects of ash particles (strongly depolarizing) and non-ash particles (very weakly depolarizing). Only the Granada system had a depolarization channel (at $532 \mathrm{~nm}$ ) operative during the period 5-8 May 2010 , so that profiles of mass concentration were only calculated for this station. For the sake of clarity, the wavelength dependency of all coefficients has been omitted in this section. We remark that the method was applied under the assumption of external mixing only. As the Eyjafjallajökull eruption was sub-glacial, it is unlikely that internal mixing such as sulfur coating on ash occurred due to the high concentration of water vapor present in the ash cloud (Thomas and Prata, 2011).

If we call $\beta$ the total aerosol backscatter coefficient, the backscatter coefficients of ash, $\beta_{\mathrm{a}}$, and non-ash particles, $\beta_{\text {na }}$, can be calculated respectively as:

$\beta_{\mathrm{a}}=\beta \frac{\left(\delta-\delta_{\mathrm{na}}\right)}{\left(\delta_{\mathrm{a}}-\delta_{\mathrm{na}}\right)} \frac{\left(1-\delta_{\mathrm{a}}\right)}{(1-\delta)} \quad$ and

$\beta_{\mathrm{na}}=\beta \frac{\left(\delta-\delta_{\mathrm{a}}\right)}{\left(\delta_{\mathrm{na}}-\delta_{\mathrm{a}}\right)} \frac{\left(1-\delta_{\mathrm{na}}\right)}{(1-\delta)}$

where $\delta$ is the linear particle depolarization ratio, and $\delta_{\mathrm{a}}$ and $\delta_{\text {na }}$ represent the ash and non-ash linear particle depolarization ratios, respectively. Pure ash and pure non-ash particle depolarization ratios are reasonably well known as $\delta_{\mathrm{a}}=0.36$ and $\delta_{\text {na }}=0.01$ (Ansmann et al., 2010; Groß et al., 2010), respectively. The mass concentrations of ash, $m_{\mathrm{a}}$, and non-ash particles, $m_{\text {na }}$, are given in terms of backscatter coefficient respectively as:

$m_{\mathrm{a}}=\rho_{\mathrm{a}} \frac{C_{\mathrm{c}}}{\mathrm{AOT}_{\mathrm{c}}} \beta_{\mathrm{a}} S_{\mathrm{a}} \quad$ and

$m_{\text {na }}=\rho_{\text {na }} \frac{C_{\mathrm{f}}}{\mathrm{AOT}_{\mathrm{f}}} \beta_{\text {na }} S_{\text {na }}$

where $\rho_{\mathrm{a}}$ and $\rho_{\mathrm{na}}$ are the ash and non-ash particle mass density, and $S_{\mathrm{a}}$ and $S_{\mathrm{na}}$ are the ash and non-ash particle lidar ratio. The two ratios, $\frac{C_{\mathrm{f}}}{\mathrm{AOT}_{\mathrm{f}}}$ and $\frac{C_{\mathrm{c}}}{\mathrm{AOT}_{\mathrm{c}}}$, also called mean extinction-to-mass conversion factors, represent the ratio of volume concentration to AOT for the fine (non-ash) and the coarse (ash) mode, respectively.

For pure ash and non-ash particles, respectively, $\rho_{\mathrm{a}}=2.6 \mathrm{~g} \mathrm{~cm}^{-3}$ (http://volcanoes.usgs.gov/ash/properties. html\{\#\} density; Schumann et al., 2011) and $\rho_{\text {na }}=1.6 \mathrm{~g} \mathrm{~cm}^{-3}$ (Bukowiecki et al., 2011), and $S_{\mathrm{a}}=50 \pm 10 \mathrm{sr}$ and $S_{\mathrm{na}}=$ $60 \pm 20 \mathrm{sr}$ (Ansmann et al., 2011). The ratios of volume concentration to AOT were calculated from AERONET-derived level 1.5 inversion products on 8 May, 2010, at 06:35 and 07:00 UTC. The size distributions associated to those inversions are shown in Fig. 8. They are very similar and exhibit an enhanced fine (non-ash) mode. Note en passant that similar size distributions have been obtained in Madrid by ground-based in-situ measurements (Revuelta et al., 2011). 
Table 3. Sun-photometer total, fine and coarse mode AOT at $500 \mathrm{~nm}$ and lidar-derived total, non-ash, and ash AOT at $532 \mathrm{~nm}$ at Granada on 8 May 2010. The numbers in parenthesis represent the fraction of AOT of the mode considered to the AOT total (AOT for the sun-photometer and $\mathrm{AOT}_{\mathrm{VA}}$ for the lidar).

\begin{tabular}{|c|c|c|c|c|c|c|}
\hline & AOT & $\mathrm{AOT}_{\mathrm{f}}$ & $\mathrm{AOT}_{\mathrm{c}}$ & $\mathrm{AOT}_{\mathrm{VA}}$ & $\int_{\text {VA laye }}$ & $\int_{\text {VA layer }} \beta_{\mathrm{a}} S_{\mathrm{a}}$ \\
\hline $\begin{array}{l}\text { Lidar } \\
04: 00 \text { UTC } \\
2.6-2.9 \mathrm{~km}\end{array}$ & & & & 0.101 & $\begin{array}{l}0.083 \\
(82 \%)\end{array}$ & $\begin{array}{l}0.018 \\
(18 \%)\end{array}$ \\
\hline $\begin{array}{l}\text { Sun-phot. } \\
\text { 06:35 UTC }\end{array}$ & 0.376 & $\begin{array}{l}0.334 \\
(89 \%)\end{array}$ & $\begin{array}{l}0.042 \\
(11 \%)\end{array}$ & & & \\
\hline $\begin{array}{l}\text { Sun-phot. } \\
\text { 07:00 UTC }\end{array}$ & 0.358 & $\begin{array}{l}0.313 \\
(87 \%)\end{array}$ & $\begin{array}{l}0.045 \\
(13 \%)\end{array}$ & & & \\
\hline $\begin{array}{l}\text { Lidar } \\
16: 00 \text { UTC } \\
3.00-3.35 \mathrm{~km}\end{array}$ & & & & 0.0025 & $\begin{array}{l}0.002 \\
(80 \%)\end{array}$ & $\begin{array}{l}0.0005 \\
(20 \%)\end{array}$ \\
\hline
\end{tabular}

This result is completely different than similar observations made in Germany at the beginning of the eruption (Ansmann et al., 2011) where the fine (non-ash) and coarse (ash) mode predominance were inverted, the enhanced mode being that of coarse (ash) particles, and where the volume concentration was higher by a factor 10 . The mean extinctionto-mass conversion factors for the fine (non-ash) and the coarse (ash) modes are $\frac{C_{\mathrm{f}}}{\mathrm{AOT}_{\mathrm{f}}}=0.255 \times 10^{-6} \mathrm{~m}$ and $\frac{C_{\mathrm{c}}}{\text { AOT }_{\mathrm{c}}}=$ $0.89 \times 10^{-6} \mathrm{~m}$, respectively.

By applying the law of error propagation to Eqs. (3) and (4), the uncertainty in the mass concentration in Fig. 9 is estimated to be about $40-45 \%$. The following individual uncertainties have been considered: $25 \%$ for the mass densities, $20 \%$ for the lidar ratios, and $15 \%$ for the mean extinctionto-mass conversion factors (Tesche et al., 2009; Ansmann et al., 2011). Concerning the particle backscatter coefficient, its uncertainty is estimated of the order of 15-20\% (see Sect. 3.2), two times higher than in the dust and smoke plumes in Cape Verde (Tesche et al., 2009). The uncertainty of the particle depolarization ratio is $6 \%$ at 04:00 UTC and $20 \%$ at 16:00 UTC. The latter two uncertainties and the uncertainty in $\delta_{\mathrm{a}}$ and $\delta_{\text {na }}$ yield an overall relative uncertainty for ash and non-ash backscatter coefficients of $\sim 20 \%$ during nighttime and $\sim 30 \%$ during daytime.

In order to justify the use of the columnar values of the mean extinction-to-mass conversion factors in the VA layers, the non-ash and the ash AOT fractions are calculated for the lidar at 04:00 and 16:00 UTC and

compared, respectively, to the fine (non-ash) and coarse (ash) mode fractions of the sun-photometer at 06:35 and 07:00 UTC. In this section the lidar-derived AOT $_{\mathrm{VA}}$ was calculated as:

$\mathrm{AOT}_{\mathrm{VA}}=\int_{\text {VA layer }}\left(\beta_{\mathrm{na}} S_{\mathrm{na}}+\beta_{\mathrm{a}} S_{\mathrm{a}}\right)$.
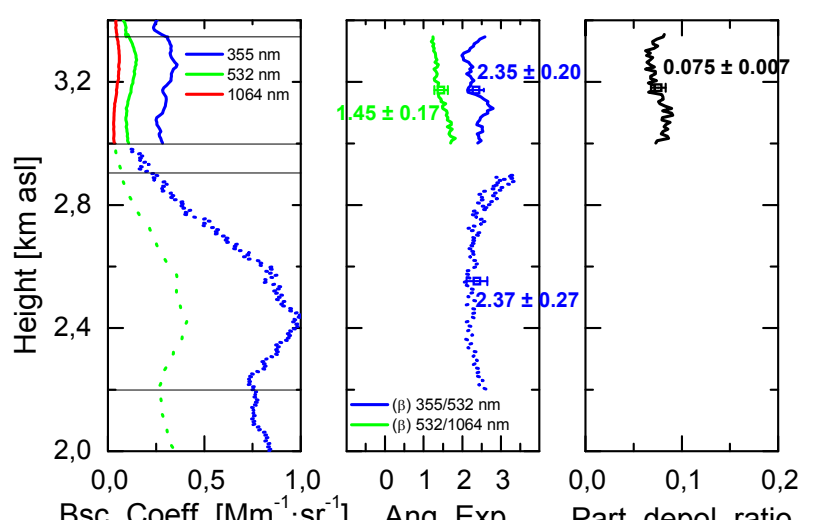

Bsc. Coeff. $\left[\mathrm{Mm}^{-1} \cdot \mathrm{sr}^{-1}\right] \quad$ Ang. Exp. Part. depol. ratio

Fig. 7. Volume backscatter coefficients, $\beta$-related Ångström exponents, and linear particle depolarization ratio on 8 May 2010 at 16:00 UTC at Granada (solid lines) and Barcelona (dot lines).

Table 3 summarizes the values found for both instruments. Even though the AERONET AOT uncertainty is known to be $\leq \pm 0.01$ for wavelengths greater than $440 \mathrm{~nm}$ (Holben et al., 1998; Dubovik et al., 2000), here the AOT at $500 \mathrm{~nm}$ is expressed with three digits in order to minimize differences due to truncation in the calculation of the fine and coarse mode fractions. For the same reason, the lidar-derived $\mathrm{AOT}_{\mathrm{VA}}$ is expressed with four digits. The VA layers at 04:00 and 16:00 UTC are found around $2.6-2.9 \mathrm{~km}$ and $3.00-3.35 \mathrm{~km}$, respectively. In those layers, the ratio of lidar-derived nonash AOT to $\mathrm{AOT}_{\mathrm{VA}}$ is nearly constant between both lidar measurements around $80-82 \%$. In the atmospheric column the sun-photometer fine (non-ash) mode fraction is around $87-89 \%$. Given the relatively good agreement between those numbers and besides the lack of size distribution measurements in the VA layers, the above-mentioned method can be further applied to our lidar measurements. 


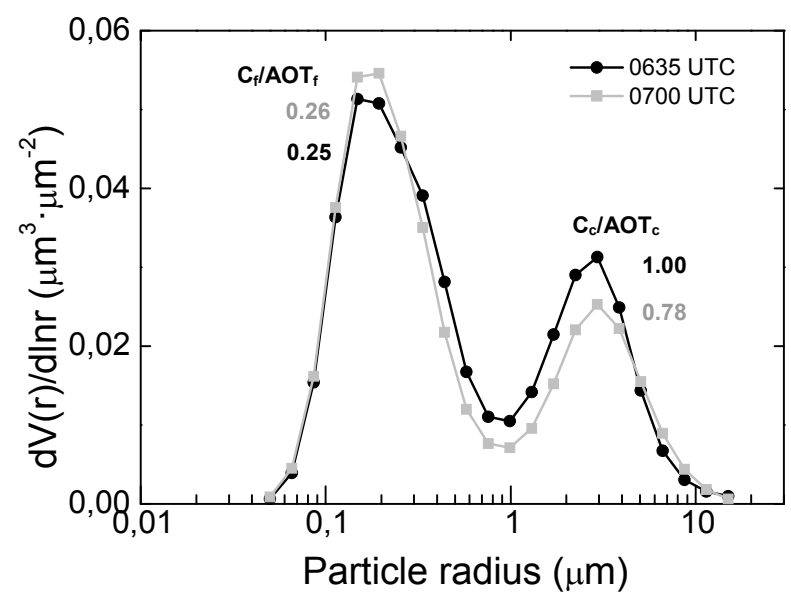

Fig. 8. AERONET size distributions at Granada on 8 May 2010, at 06:35 and 07:00 UTC. The ratio of volume concentration to AOT for the fine (non-ash) and the coarse (ash) mode are indicated in black at 06:35 UTC and in gray at 07:00 UTC.
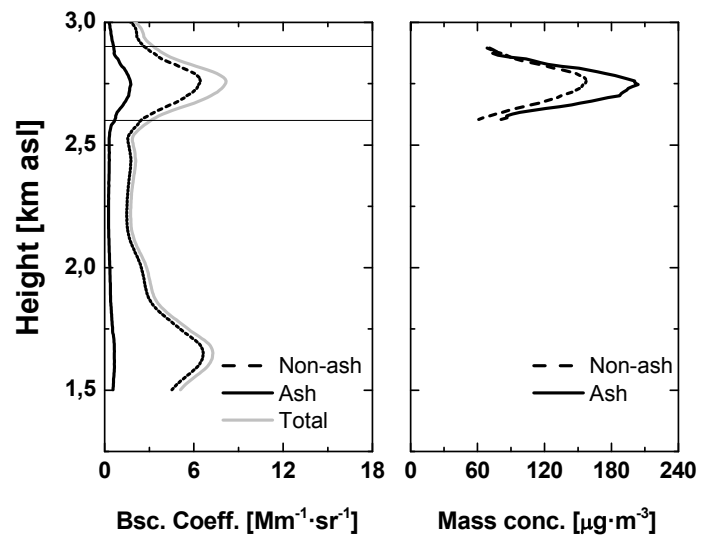

(a)
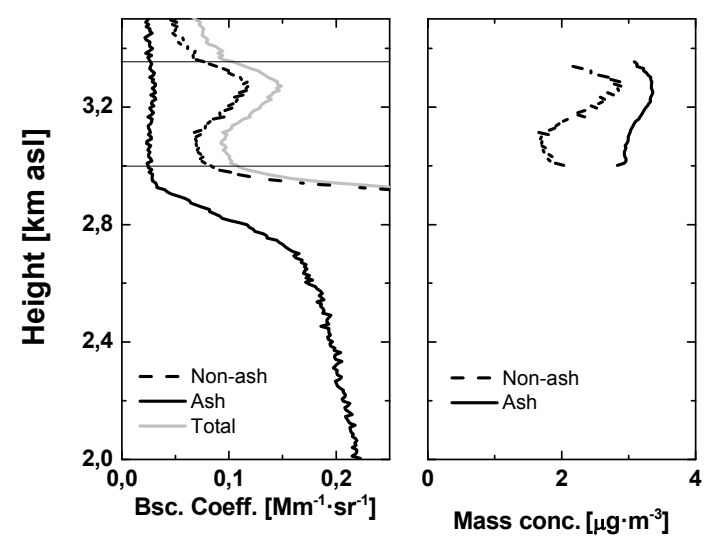

Fig. 9. Mass concentration profiles of ash and non-ash particles at Granada on 8 May 2010, at (a) 04:00 and (b) 16:00 UTC.
The results are shown in Fig. 9 for the VA layers identified at $2.6-2.9 \mathrm{~km}$ at $04: 00 \mathrm{UTC}$ and at $3.00-3.35 \mathrm{~km}$ at 16:00 UTC. As a consequence of the low particle depolarization ratios observed around 0.06-0.075 (see Figs. 6 and 7) compared to central Europe (Ansmann et al., 2010, 2011) or central Mediterranean (Mona et al., 2011) the ash and non-ash particle mass concentrations appear approximately in the same order of magnitude. They roughly fluctuate in the range $60-180 \mu \mathrm{gm}^{-3}$ at $04: 00 \mathrm{UTC}$ and $1.5-3.5 \mu \mathrm{gm}^{-3}$ at 16:00 UTC. In the afternoon, the mass concentration is around 30 to 50 times smaller than what is observed at 04:00 UTC. Those proportions are also reflected by the difference observed between both $\mathrm{AOT}_{\mathrm{VA}}$. It is worth noting that the $\mathrm{AOT}_{\mathrm{VA}}$ at Granada reaches the highest values of the period in the night between 7 and 8 May (see Fig. 4) without a significant change, either in the thickness of the layers or in the particle depolarization ratio. Thus it leads to high values of the backscatter coefficient and also of the mass concentration. It is quite probable that the mass concentration of neither the ash nor the non-ash particles found in lofted VA layers exceeded the value of $200 \mu \mathrm{g} \mathrm{m}^{-3}$ in Granada in the period 5-8 May 2010.

\section{Conclusions}

During the Eyjafjallajökull eruption, the strongest intrusion of volcanic aerosols in the Iberian Peninsula occurred during 5-8 May 2010. Volcanic aerosols were first observed at the westernmost lidar station in Évora. Lofted VA layers showed a downward motion from 6 May onwards. The mean AOT of those layers was rather low (between 0.013 and 0.020 in all stations over the whole period) with a peak on 7 May. Even though the thickness of the VA layers was spatially and temporally quite variable, rather thin layers $(<1000 \mathrm{~m})$ with a top height up to $11-12 \mathrm{~km}$ were observed. A significant increase in the total AOT, as well as in the fine mode AOT, is observed along the intrusion which indicates an increase of the aerosol load of rather small size in the PBL since the lofted VA layers optical thickness did not change significantly during the intrusion. The backtrajectory analysis which shows transport time from Iceland on the order of 3 days at the beginning of the period and on the order of 5 days at the end corroborates this result: the size of the lofted VA decreases with increasing age. Contrarily to lidar stations from northern and central Europe that detected optically very thick lofted VA layers, most of the VA that reached the IP were already coupled to the PBL. In general the presence of volcanic aerosols was also supported by satellite images and/or FLEXPART simulations.

Lidar ratios at different sites varied between 30 and $50 \mathrm{sr}$ without a marked spectral dependency between 355 and $532 \mathrm{~nm}$. Values near $50 \mathrm{sr}$ were observed on 7 May over Madrid in high VA layers above $4 \mathrm{~km}\left(\mathrm{AOT}_{\mathrm{VA}}=0.095\right.$ at $532 \mathrm{~nm}$ ) and on 8 May over Granada in VA layers between 
2.5 and $3.0 \mathrm{~km}\left(\mathrm{AOT}_{\mathrm{VA}}=0.078\right.$ at $\left.532 \mathrm{~nm}\right)$. Smaller values between 30 and $40 \mathrm{sr}$ were observed over Évora on 7 May in a VA layer between 2.5 and $4.0 \mathrm{~km}\left(\mathrm{AOT}_{\mathrm{VA}}=0.070\right.$ at $532 \mathrm{~nm}$ ). Similar extinction-related Ångström exponents varying between 0.6 and 0.8 were observed in Évora and Granada. In terms of backscatter-related Ångström exponents, an increase is observed between sites with time: e.g. at $355 / 532 \mathrm{~nm}, 0.22$ is measured in Évora on 7 May, 0.73 is measured in Granada on 8 May (morning), and $\sim 2.35$ is measured in Granada and Barcelona on 8 May (afternoon). This result points out a possible decrease of the volcanic particle size as the plume moves from west to east. The relatively low linear particle depolarization ratio at $532 \mathrm{~nm}$ measured in the VA layers in Granada around 0.065-0.075 further indicates the coexistence of ash and non-ash particles.

An estimate of the mass concentration of ash and non-ash particles has been performed in Granada by using the opposite depolarizing effects of ash particles (strongly depolarizing) and non-ash particles (very weakly depolarizing), and sun-photometer observations. In the morning of 8 May, both the ash and non-ash mass concentration varied between 60 and $180 \mathrm{\mu gm}^{-3}$ in a VA layer with an optical thickness of 0.101 . Later the mass concentration varied between 1.5 and $3.5 \mu \mathrm{gm}^{-3}$ in a VA layer with an optical thickness of 0.0025 . In both cases, the ash mass concentration was approximately 1.5 higher than the non-ash mass concentration. Given that the case selected in the morning of 8 May had one of the highest optical thicknesses, it is quite probable that the mass concentration of neither the ash nor the nonash particles found in lofted VA layers exceeded the value of $200 \mu \mathrm{gm}^{-3}$ in Granada in the period 5-8 May 2010. If we extrapolate this result to the entire Iberian Peninsula, it is most probable that the societal inconvenience created by the air travel disruption over the IP pointed out an overreaction from policy makers.

\section{Appendix A}

\section{Calculation of the uncertainty of $\mathrm{AOT}_{\mathrm{VA}}$}

The uncertainty of $\mathrm{AOT}_{\mathrm{VA}}$ can be deduced from the uncertainty of the backscatter coefficient profiles. There are two terms to consider:

- The systematic error $\left(d \beta_{\text {syst }}\right)$ : the sum of the error due to a range-dependent lidar ratio and the error due to an erroneous backscatter coefficient at the calibration height;

- The statistical error $\left(d \beta_{\text {stat }}\right)$ due to the observation noise.

On the one hand, the systematic errors, $d\left(\mathrm{AOT}_{\mathrm{VA}}\right)_{\text {syst }}$, are correlated with range, so that the variance associated to $\mathrm{AOT}_{\mathrm{VA}}$ due to systematic errors falls like $1 / N^{2}$ (Barlow,
1989), being $N$ the number of samples in the VA layer and $S$ the lidar ratio:

$$
V\left(\mathrm{AOT}_{\mathrm{VA}}\right)_{\mathrm{syst}}=\frac{\left[d\left(\mathrm{AOT}_{\mathrm{VA}}\right)_{\mathrm{syst}}\right]^{2}}{N^{2}} \text { and }
$$

$d\left(\mathrm{AOT}_{\mathrm{VA}}\right)_{\mathrm{syst}}=N \cdot\left[V\left(\mathrm{AOT}_{\mathrm{VA}}\right)_{\text {syst }}\right]^{\frac{1}{2}}=N \cdot S \cdot\left[\int_{\mathrm{VA} \text { layer }} \frac{1}{N^{2}} d \beta_{\text {syst }}^{2}(u) d u\right]^{\frac{1}{2}}$.

On the other hand, the statistical error, $d\left(\mathrm{AOT}_{\mathrm{VA}}\right)_{\text {stat }}$ is uncorrelated with range, so that the variance associated to AOT $_{\mathrm{VA}}$ due to the statistical error falls now like 1/ $N$ (Barlow, 1989):

$V\left(\mathrm{AOT}_{\mathrm{VA}}\right)_{\mathrm{stat}}=\frac{\left[d\left(\mathrm{AOT}_{\mathrm{VA}}\right)_{\mathrm{stat}}\right]^{2}}{N}$ and

$d\left(\mathrm{AOT}_{\mathrm{VA}}\right)_{\text {stat }}=\sqrt{N} \cdot\left[V\left(\mathrm{AOT}_{\mathrm{VA}}\right)_{\text {stat }}\right]^{\frac{1}{2}}=\sqrt{N} \cdot S \cdot\left[\int_{\mathrm{VA} \text { layer }} \frac{1}{N} d \beta_{\text {stat }}^{2}(u) d u\right]^{\frac{1}{2}}$.

Acknowledgements. This work is supported by the 7th Framework Programme project Aerosols, Clouds, and Trace Gases Research Infrastructure Network (ACTRIS) (grant agreement no. 262254); by the MICINN (Spanish Ministry of Science and Innovation) and FEDER funds under the project TEC2009-09106/TEC and UNPC10-4E-442, and the Complementary Actions CGL201009225-E and CGL2011-13580-E/CLI; by the Spanish Ministry of Education under the project PR2011-0358. It has also been supported by FCT (Fundacão para a Ciência e a Tecnologia) through the National Re-equipment Program REDE/1527/RNG/2007. Jana Preißler was funded by FCT (grant SFRH/BD/47521/2008). Juan Luis Guerrero-Rascado was partially funded by FCT (grant SFRH/BPD/63090/2009) and by the Spanish Ministry of Education (grant EX2009-0700). The authors gratefully acknowledge the Earth Sciences Division of the Barcelona Supercomputing Center and the Universidad de Extremadura for the use of the Barcelona and Cáceres AERONET sun-photometer data, respectively, and the NOAA Air Resources Laboratory (ARL) for the provision of the HYSPLIT transport and dispersion model and READY website (http://www.arl.noaa.gov/ready.html) used in this publication. The Barcelona team wishes to acknowledge the gracious collaboration of Fernando Comerón who helped to set up the lidar on 8 May 2010 after the flight he was supposed to take was cancelled because of the closure of the Barcelona airspace.

Edited by: F. Prata 


\section{References}

Alados-Arboledas, L., Lyamani, H., and Olmo, F. J.: Aerosol size properties at Armilla, Granada (Spain), Q. J. R. Meteorol. Soc., 129, 1395-1413, 2003.

Ansmann, A., Riebesell, M., and Weitkamp, C.: Measurement of atmospheric aerosol extinction profiles with a Raman lidar, Opt. Letters, 15, 746-748, 1990.

Ansmann, A., Wandinger U., Riebesell M., Weitkamp C., and Michaelis W.: Independent measurement of extinction and backscatter profiles in cirrus-clouds by using a combined Raman elastic-backscatter lidar, Appl. Optics, 31, 7113-7131, 1992.

Ansmann, A., Tesche, M., Groß, S., Freudenthaler, V., Seifert, P., Hiebsch, A., Schmidt, J., Wandinger, U., Mattis, I., Müller, D., and Wiegner M.: The 16 April 2010 major volcanic ash plume over central Europe: 27 EARLINET lidar and AERONET photometer observations at Leipzig and Munich, Germany, Geophys. Res. Lett., 37, L13810, doi:10.1029/2010GL043809, 2010.

Ansmann, A., Tesche M., Seifert P., Groß, S., Freudenthaler, V., Apituley, A., Wilson, K. M., Serikov, I., Linné , H., Heinold, B., Hiebsch, A., Schnell, F., Schmidt, J., Mattis, I., Wandinger, U., and Wiegner, M.: Ash and fine mode particle mass profiles from EARLINET-AERONET observations over central Europe after the eruptions of the Eyjafjallajökull volcano in 2010, J. Geophys. Res., 116, D00U02, doi:10.1029/2010JD015567, 2011.

Barlow, R. J. (Ed.): Statistics. A Guide to the Use of Statistical Methods in Physical Sciences, Wiley, Chichester, United Kingdom, 1989.

Borrmann, S., Dye, J. E., Baumgardner, D., Proffitt, M. H., Margitan, J. J., Wilson, J. C., Jonsson, H. H., Brock, C. A., Loewenstein, M., Podolske, J. R., and Ferry, G. V.: Aerosols as dynamic tracers in the lower stratosphere, J. Geophys. Res., 100, 1114711156, 1995.

Bukowiecki, N., Zieger, P., Weingartner, E., urányi, Z., Gysel, M., Neininger, B., Schneider, B., Hueglin, C., Ulrich, A., Wichser, A., Henne, S., Brunner, D., Kaegi, R., Schwikowski, M., Tobler, L., Wienhold, F. G., Engel, I., Buchmann, B., Peter, T., and Baltensperger, U.: Ground-based and airborne in-situ measurements of the Eyjafjallajökull volcanic aerosol plume in Switzerland in spring 2010, Atmos. Chem. Phys., 11, 10011-10030, doi:10.5194/acp-11-10011-2011, 2011.

Di Girolamo, P., Pappalardo, G., Spinelli, N., Berardi, V., and Velotta, R.: Lidar observations of the stratospheric aerosol layer over southern Italy in the period 1991-1995, J. Geophys. Res., 101, 18765-18774, 1996.

Dubovik, O., Smirnov, A., Holben, B. N., King, M. D., Kaufman, Y. J., Eck, T. F., and Slutsker, I.: Accuracy assessments of aerosol optical properties retrieved from Aerosol Robotic Network (AERONET) Sun and sky radiance measurements, J. Geophys. Res., 105, D8, 9791-9806, 2000.

Draxler, R. R. and Rolph G. D.: NOAA AirResources Laboratory, Silver Spring, MD, availabla at: http://www.arl.noaa.gov/ready/ hysplit4.html, 2003.

Emeis, S., Forkel, R., Junkermann, W., Schäfer, K., Flentje, H., Gilge, S., Fricke, W., Wiegner, M., Freudenthaler, V., Groß, S., Ries, L., Meinhardt, F., Birmili, W., Münkel, C., Obleitner, F., and Suppan, P.: Measurement and simulation of the 16/17 April 2010 Eyjafjallajökull volcanic ash layer dispersion in the northern Alpine region, Atmos. Chem. Phys., 11, 2689-2701, doi:10.5194/acp-11-2689-2011, 2011.
Escudero, M., Stein, A., Draxler, R. R., Querol, X., Alastuey, A., Castillo, S., and Avila, A.: Determination of the contribution of Northern Africa dust source areas to $\mathrm{PM}_{10}$ concentrations over Central Iberian Peninsula using the HYSPLIT model, J. Geophys. Res., 111, D06210, doi:10.1029/2005JD006395, 2006.

Fernald, F. G.: Analysis of atmospheric lidar observations: some comments, Appl. Optics, 23, 652-653, 1984.

Flentje, H., Claude, H., Elste, T., Gilge, S., Köhler, U., PlassDülmer, C., Steinbrecht, W., Thomas, W., Werner, A., and Fricke, W.: The Eyjafjallajökull eruption in April 2010 - detection of volcanic plume using in-situ measurements, ozone sondes and lidar-ceilometer profiles, Atmos. Chem. Phys., 10, 1008510092, doi:10.5194/acp-10-10085-2010, 2010.

Freudenthaler, V., Amodeo, A., and Serikov, I.: Report on IC-campaign, part 1+2, Deliverable D3.6, EARLINET-ASOS project, Contract [RICA-CT-2006-025991], 2011.

Gasteiger, J., Groß, S., Freudenthaler, V., and Wiegner, M.: Volcanic ash from Iceland over Munich: mass concentration retrieved from ground-based remote sensing measurements, Atmos. Chem. Phys., 11, 2209-2223, doi:10.5194/acp-11-22092011, 2011.

Groß, S., Gasteiger, J., Freudenthaler, V., Schnell, F., and Wiegner, M.: Characterization of the Eyjafjallajökull ash-plume by means of lidar measurements over the Munich EARLINET site, Proceedings of SPIE, SPIE Remote Sensing 2010, Toulouse, 20-23 September 2010, 7832, doi:10.1117/12.869020, 2010.

Holben, B., Eck, T. F., Slutsker, I., Tanré, D., Buis, J. P., Setzer, A., Vermote, E., Reagan, J. A., Kaufman, Y. J., Nakajima, T., Lavenu, F., Jankowiak, I., and Smirnov, A.: AERONET - A federated instrument network and data archive for aerosol characterization, Remote Sens. Env., 66, 1-16, 1998.

Klett, J. D.: Lidar inversion with variable backscatter/extinction ratios, Appl. Optics, 24, 1638-1643, 1985.

Langford, A. O., O’Leary, T. J., Proffitt, M. H., and Hitchman, M. H.: Transport of the Pinatubo volcanic aerosol to northern midlatitude site, J. Geophys. Res., 100, 9007-9016, 1995.

Langmann, B., Folch, A., Hensch, M., and Matthias, V.: Volcanic ash over Europe during the eruption of Eyjafjallajökull on Iceland, April-May 2010, Atmos. Environ., 48, 1-8, doi:10.1016/j.atmosenv.2011.03.054, 2012.

Molero, F., Sicard, M., Guerrero-Rascado, J. L., Navas-Guzmán, F., Tomás, S., Preißler, J., Kumar, D., Rocandenbosch, F., AladosArboledas, L., Wagner, F., Comeron, A., and Pujadas, M.: Comparison of SPALINET network lidar measurements with models forecasts during the Eyjafjalla event, 25th International Laser Radar Conference, Saint-Petersburg, Russia, 5-9 July 2010.

Mona, L., Amodeo, A., D’Amico, G., Giunta, A., Madonna, F., and Pappalardo, G.: Multi-wavelength Raman lidar observations of the Eyjafjallajökull volcanic cloud over Potenza, southern Italy, Atmos. Chem. Phys., 12, 2229-2244, doi:10.5194/acp-12-22292012, 2012.

O’Neill, N. T., Eck, T. F., Smirnov, A., Holben, B. N., and Thulasiraman, S.: Spectral discrimination of coarse and fine mode optical depth, J. Geophys. Res., 108, D17, 4559-4573, doi:10.1029/2002JD002975, 2003.

Papayannis, A., Mamouri, R. E., Amiridis, V., Giannakaki, E., Veselovskii, I., Kokkalis, P., Tsaknakis, G., Balis, D., Kristiansen, N. I., Stohl, A., Korenskiy, M., Allakhverdiev, K., Huseyinoglu, M. F., and Baykara, T.: Optical properties 
and vertical extension of aged ash layers over the Eastern Mediterranean as observed by Raman lidars during the Eyjafjallajökull eruption in May 2010, Atmos. Environ., 48, 56-65, doi:10.1016/j.atmosenv.2011.08.037, 2011.

Pappalardo, G., Amodeo, A., Mona, L., Pandolfi, M., Pergola, N., and Cuomo, V.: Raman lidar observations of aero-sol emitted during the 2002 Etna eruption, Geophys. Res. Lett., 31, L05120, doi:10.1029/2003GL019073, 2004.

Pappalardo, G., Amodeo, A., Ansmann, A., Apituley, A., Alados Arboledas, L., Balis, D., Böckmann, C., Chaikovsky, A., Comeron, A., D’Amico, G., De Tomasi, F., Freudenthaler, V., Giannakaki, E., Giunta, A., Grigorov, I., Gustafsson, O., Gross, S., Haeffelin, M., Iarlori, M., Kinne, S., Linné, H., Madonna, F., Mamouri, R., Mattis, I., McAuliffe, M., Molero, F., Mona, L., Müller, D., Mitev, V., Nicolae, D., Papayannis, A., Perrone, M. R., Pietruczuk, A., Pujadas, M., Putaud, J.-P., Ravetta,F., Rizi, V., Serikov, I., Sicard, M., Simeonov, V., Spinelli, N., Stebel, K., Trickl, T., Wandinger, U., Wang, X., Wagner, F., and Wiegner, M.: EARLINET observations of the Eyjafjallajöokull ash plume over Europe, in: "Lidar Technologies, Techniques, and Measurements for Atmospheric Remote Sensing VI", Proceedings of SPIE, SPIE Remote Sensing 2010, Toulouse, 20-23 September 2010, 7832-17, 2010.

Pappalardo, G., Mona, L., Adam, M., Apituley, A., Arboledas, L. A., Chaikovsky, A., Cuesta, J., de Tomasi, F., D’Amico, G., Giannakaki, E., Grigorov, I., Gross, S., Iarlori, M., Mamouri, R. E., Mattis, I., Mitev, V., Nicolae, D., Pietruczuk, A., Serikov, I., Sicard, M., Simenov, V., Spinelli, N., Trickl, T., and Wagner, F.: 4D distribution of the 2010 Eyjafjallajökull volcanic cloud over Europe observed by EARLINET, Atmos. Chem. Phys., in preparation, 2012.

Parker, D. E., Wilson, H., Jones, P. D., Christy, J. R., and Folland, C. K.: The impact of mount Pinatubo on world-wide temperatures, Int. J. Climatol., 16, 487-497, 1996.

Revuelta, M. A., Sastre, M., Fernández, A. J., Martín, L., García, R., Gómez-Moreno, F. J., Artínano, B., Pujadas, M., and Molero, F.: Characterization of the Eyjafjallajökull volcanic plume over the Iberian Peninsula by lidar remote sensing and ground-level data collection, Atmos. Environ., 48, 46-55, doi:10.1016/j.atmosenv.2011.05.033, 2012.

Rolph, G. D.: NOAA Air Resources Laboratory, Silver Spring, MD, http://www.arl.noaa.gov/ready/hysplit4.html, 2003.

Sasano, Y. and Nakane, H.: Significance of the extinction/backscatter ratio and the boundary value term in the solution for the two-component lidar equation, Appl. Optics, 23, 11-13, 1984.

Schumann, U., Weinzierl, B., Reitebuch, O., Schlager, H., Minikin, A., Forster, C., Baumann, R., Sailer, T., Graf, K., Mannstein, H., Voigt, C., Rahm, S., Simmet, R., Scheibe, M., Lichtenstern, M., Stock, P., Rüba, H., Schäuble, D., Tafferner, A., Rautenhaus, M., Gerz, T., Ziereis, H., Krautstrunk, M., Mallaun, C., Gayet, J.-F., Lieke, K., Kandler, K., Ebert, M., Weinbruch, S., Stohl, A., Gasteiger, J., Groß, S., Freudenthaler, V., Wiegner, M., Ansmann, A., Tesche, M., Olafsson, H., and Sturm, K.: Airborne observations of the Eyjafjalla volcano ash cloud over Europe during air space closure in April and May 2010, Atmos. Chem. Phys., 11, 2245-2279, doi:10.5194/acp-11-2245-2011, 2011.
Sicard, M., Molero, F., Guerrero-Rascado, J. L., Pedrós, R., Expósito, F. J., Córdoba-Jabonero, C., Bolarín, J. M., Comerón, A., Rocadenbosch, F., Pujadas, M., Alados-Arboledas, L., Martinez-Lozano, J. A., Díaz, J. P., Gil, M., Requena, A., NavasGuzmán, F., and Moreno, J. M.: Aerosol lidar intercomparison in the framework of SPALINET - the SPAnish LIdar NETwork: methodol-ogy and results, IEEE Trans. Geosci. Remote Sens., 47, 3547-3559, 2009.

Sicard, M., Pujadas, M., Alados-Arboledas, L., Pedrós, R., Díaz, J. P., Córdoba-Jabonero, C., Requena, A., Comerón, A., Rocadenbosch, F., Wagner, F., Rodrigues, J., Moreno, J. M.: SPALINET: The Spanish and Portuguese aerosol lidar network, Opt. Pura Appl., 44, 1-5, 2011 a.

Sicard, M., Rocadenbosch, F., Reba, M. N. M., Comerón, A., Tomás, S., García-Vízcaino, D., Batet, O., Barrios, R., Kumar, D., and Baldasano, J. M.: Seasonal variability of aerosol optical properties observed by means of a Raman lidar at an EARLINET site over Northeastern Spain, Atmos. Chem. Phys., 11, doi:10.5194/acp-11-175-2011, 2011 .

Stohl, A., Prata, A. J., Eckhardt, S., Clarisse, L., Durant, A., Henne, S., Kristiansen, N. I., Minikin, A., Schumann, U., Seibert, P., Stebel, K., Thomas, H. E., Thorsteinsson, T., Trseth, K., and Weinzierl, B.: Determination of time- and height-resolved volcanic ash emissions and their use for quantitative ash dispersion modeling: the 2010 Eyjafjallajökull eruption, Atmos. Chem. Phys., 11, 4333-4351, doi:10.5194/acp-11-4333-2011, 2011.

Tesche, M., Ansmann, A., Müller, D., Althausen, D., Engelmann, R., Freudenthaler, V., and Groß, S.: Vertically resolved separation of dust and smoke over Cape Verde using multiwavelength Raman and polarization lidars during Saharan Mineral Dust Experiment 2008, J. Geophys. Res., 114, D13202, doi:10.1029/2009JD011862, 2009.

Thomas, H. E. and Prata, A. J.: Sulphur dioxide as a volcanic ash proxy during the AprilMay 2010 eruption of Eyjafjallajökull Volcano, Iceland, Atmos. Chem. Phys., 11, 6871-6880, doi:10.5194/acp-11-6871-2011, 2011.

Toledano, C., Bennouna, Y., Cachorro, V., Ortiz de Galisteo, J. P., Stebel, K., Kristiansen, N. I., Olmo, F. J., Lyamani, H., Obregón, M. A., Estellés, V., Wagner, F., Baldasano, J. M., GonzálezCastanedo, Y., Clarisse, L., and de Frutos, A. M.: Aerosol properties derived from Sun photometer and satellite observations of the Eyjafjallajökull ashes over the Iberian Peninsula, Atmos. Environ., 48, 22-32, doi:10.1016/j.atmosenv.2011.09.072, 2012.

Villani, M. G., Mona, L., Maurizi, A., Pappalardo, G., Tiesi, A., Pandolfi, M., D’Isidoro, M., Cuomo, V., and Tampieri, F.: Transport of volcanic aerosol in the troposphere: the case study of the 2002 Etna plume, J. Geophys. Res., 111, D21102, doi:10.1029/2006JD007126, 2006.

Wandinger, U., Ansmann, A., Reichardt, J., and Deshler, T.: Determination of stratospheric aerosol microphysical properties from independent extinction and backscattering measurements with a Raman lidar, Appl. Optics, 34, 8315-8329, 1995.

Wang, X., Boselli, A., D’Avino, L., Pisani, G., Spinelli, N., Amodeo, A., Chaikovsky, A., Wiegner, M., Nickovic, S., Papayannis, A., Perrone, M. R., Rizi, V., Sauvage, L., and Stohl, A.: Volcanic dust characterization by EARLINET during Etna's eruptions in 2001-2002, Atmos. Environ., 42, 893-905, 2008. 
Wiegner, M., Gasteiger, J., Groß, S., Schnell, F., Freudenthaler, V., and Forkel, R.: Characterization of the Eyjafjallajökull ashplume: Potential of lidar remote sensing, J. Phys. Chem. Earth, in press, doi:10.1016/j.pce.2011.01.006, 2011.
Winker, D. M., Vaughan, M. A., Omar, A. H., Hu, Y., Powell, K. A., Liu, Z., Hunt, W. H., and Young, S. A.: Overview of the CALIPSO mission and CALIOP data processing algorithms, J. Atmos. Oceanic Technol., 26, 2310-2323, doi:10.1175/2009JTECHA1281.1, 2009. 